\title{
Genetic Linkage Analysis
}

National Cancer Institute

\section{Source}

National Cancer Institute. Genetic Linkage Analysis. NCI Thesaurus. Code C16797.

The process of measuring the extent of crossovers between chromosomes as a gauge

of the distance between genes. 